\title{
ANALISIS USAHA TERNAK BABI DI KECAMATAN SONDER KABUPATEN MINAHASA
}

\author{
Marsel J. Sarajar, F. H. Elly *, E. Wantasen, S. J. K. Umboh \\ Fakultas Peternakan Universitas Sam Ratulangi Manado, 95115
}

\begin{abstract}
ABSTRAK
Ternak babi dikembangkan oleh masyarakat di Kab Minahasa sebagai suatu usaha yang menunjang perekonomian peternak.Pengembangan usaha ternak babi di daerah ini dilakukan dalam rangka untuk mendorong peningkatan konsumsi protein hewani.Permsalahannya pengembangan peternakan babi tidak kontinyu dan belum diketahui faktor yang mempengaruhi produksi ternak babi.Penelitian ini dilakukan dengan tujuan untuk menganalisis faktor produksi yang mempengaruhi produksi ternak babi di Kecamatan Sonder Kab Minahasa.Metode penelitian yang digunakan adalah metode survey dengan pengamatan langsung di lapangan.Sumber data yang dikumpulkan adalah data primer dan data sekunder.Sampel lokasi dan responden ditentukan dengan menggunakan metode Cluster Random Sampling adalah pengambilan sampel secara acak berkelompok, bukan terhadap subjek secara individual.Analisis data yang digunakan adalah analisis deskriptif.Hasil penelitian menunjukkan bahwa ternak babi dijual dalam bentuk ternak bibit dan daging per kg.Harga bibit babi $\mathrm{Rp}$ 900.000/ekor dan harga daging $\mathrm{Rp}$ $60.000 / \mathrm{kg}$. Berdasarkan hasil penelitian menunjukkan bahwa faktor pakan, tenaga kerja dan luas kandang secara bersama sama berpengaruh nyata terhadap produksi babi.
\end{abstract}

Kata Kunci :Ternak Babi, kandang, tenaga kerja, pakan

*Korespondensi (corresponding author) Email :femi_elly@yahoo.co.id

\section{ABSTRACT}

ANALYSIS OF PIG FARMING IN SONDERDISTRICTMINAHASA

REGENCY. Pigs are developed by the community in Minahasa Regency as a business that supports the livestock farmers' economy. The development of pig farming in this area was carried out in order to increase consumption of animal protein. The problem is that the development of pig farms is not continuous and there have not known factors that influence pork production. This research was conducted with the aim of analyzing production factors that influence the production of pig farming in Sonder District, Minahasa Regency. Survey method was used with direct observation in the field. Sources of data collected are primary and secondary data. Location samples and respondents were determined by using of Cluster Random Sampling metho. Data analysis was conducted by useing descriptive analysis. The results showed that pigs were sold in the form of seeds (starter period pigs) and pork per $\mathrm{kg}$. The price of seeds is Rp. 900,000 per head and the price of pork is Rp. 60,000 per kg. Based on the study results showed that the factors such as feed, labor and cage simultaneously had a significant effect on pig production.

Keywords: Pigs, cages, labor, feed

\section{PENDAHULUAN}

Pembangunan ekonomi perlu didasarkan pada keunggulan yang dimiliki suatu daerah, termasuk di Propinsi 
Sulawesi Utara yang perlu dicapai dengan menggunakan pendekatan potensi yang dimiliki setiap daerah (Mangun, 2007).Babi merupakan salah satu komoditi ternak yang memiliki potensi besar untuk dikembangkan karena memiliki keunggulan tersendiri, antara lain laju pertumbuhannya yang cepat dan permintaan terhadap daging babi yang diperoleh cukup tinggi, yaitu sekitar satu juta kilo per tahun(Direktorat Jendral, Peternakan. 2013).

Usaha beternak babi mempunyai dua tujuan yaitu untuk menghasilkan daging dan untuk memperoleh keuntungan maksimum. Usaha ternak babi diusahakan petani sebagai sumber pendapatan mereka (Kojo at al, 2014).Produksi maksimal tergantung pakan, penyakit dan manajemen yang diterapkan (Tilman at $a l, 1986)$.Faktor-faktor tersebut berdampak terhadap peningkatan pendapatan petani.Usaha peternakan babi dapat memberikan keuntungan yang maksimum apabila petani memperhatikan alokasi penggunaan faktor produksi disamping manajemen yang baik.

Ternak babi dikembangkan oleh masyarakat di Kabupaten Minahasa sebagai suatu usaha yang menunjang perekonomian petani peternak.Pengembangan usaha ternak babi di daerah ini dilakukan dalam rangka untuk mendorong peningkatan konsumsi protein hewani.Peran ternak babi sebagai penyedia bahan protein tinggi dalam bentuk daging tidak diragukan lagi dan kenyataan ini telah berlangsung sejak lama.Permintaan terhadap daging terus meningkat, sehingga apabila tidak diimbangi dengan peningkatan produksi maka impor daging babi dapat terjadi (Aritonang dan Lerbin, 2005).Permsalahannya pengembangan peternakan babi tidak kontinyu dan belum diketahui faktor-faktor yang mempengaruhi produksi ternak babi.Penelitian ini dilakukan dengan tujuan untuk menganalisis faktor produksi yang mempengaruhi produksi ternak babi di Kecamatan Sonder Kabupaten Minahasa.

\section{METODOLOGI PENELITIAN}

Penelitian ini dilaksanakan di Kecamatan SonderKabupaten Minahasa, pada bulan September sampai November 2018.Data yang digunakan dalam penelitian ini terdiri dari dua jenis yaitu data cross section dan time series. Sumber data adalah data primer dan data sekunder.Data primer diperoleh dari hasil wawancara dengan petani peternak babi di Kecamatan Sonder.Data sekunder diperoleh dari studi literatur dari berbagai buku maupun jurnal ilmiah dan instansi yang terkait dengan penelitian ini.Sampel lokasi ditentukan dengan menggunakan metode purposive sampling. Desa 
Talikuran, Talikuran Satu, Tounelet Satu, Kauneran dan Kauneran Satu dipilih berdasarkan pertimbangan bahwa kelima desa tersebut memiliki populasi ternak babi terbanyak. Responden ditentukan dengan menggunakan metode cluster random sampling. Pertama populasi petani peternak babi dikelompok berdasarkan tujuan usaha ternak babi yaitu untuk pembibitan dan penggemukan.Kemudian berdasarkan populasi petani peternak babi sesuai dengan tujuan usaha, responden diambil secara acak (Simple Random Sampling).Analisis data yang digunakan dalam penelitian ini adalah analisis regresi berganda dengan pendekatan ekonometrika menggunakan software SAS versi 9.4.

\section{HASIL DAN PEMBAHASAN}

Usaha ternak babi sudah lama dikenal dan dikembangkan oleh masyarakat pedesaan.Jenis bangsa babi yang sering dikembangkan oleh petani peternak adalah jenis babi Landrace dan babi Duroc (Nuryasa, 2015).

Keberhasilan usaha ternak babi tergantung pada karakteristik petani diantaranya umur, pendidikan, lama usaha dan pekerjaan utama dari petani.Hasil penelitian menunjukkan umur responden sebagian besar dikategorikan umur produktif. Petani berumur 36-45sekitar 20 orang atau 66,6\%, kisaran umur 26-35 sekitar 5 orang atau $16,6 \%$, kisaran umur
46-55 sekitar 3 atau 10\%. Umur sangat mempengaruhi produktifitas tenaga kerja.Menurut beberapa hasil penelitian bahwa tingkat umur produktif berkisar pada 15-64 tahun.Hasil penelitian Suranjaya et al. (2017) menunjukkan sebagian besar responden berumur 20-55 tahun dan dikategorikan umur produktif.Umur mempengaruhi seseorang dalam hal keterampilan dan pengalaman serta penyerapan teknologi dalam mengembangkan usaha taninya.

Pendidikan merupakan salah satu sarana penunjang dalam pembangunan baik dalam sektor pertanian termasuk peternakan, sektor industri dan jasa.Tingkat pendidikan responden juga merupakan salah satu karakteristik yang mempengaruhi keberhasilan usaha peternakan babi.Pendidikan mempunyai pengaruh bagi petani dalam mengadopsi teknologi dan keterampilan manajemen dalam mengelola usahanya. Pendidikan dari seseorang berpengaruh terhadap cara berpikir sehingga mereka dapat memperhitungkan pekerjaan yang menguntungkan dan merugikan.Hasil penelitian menunjukkan bahwa tingkat pendidikan responden mulai dari yang tertinggi, tamatan peguruan tinggi dan yang terendah tamatan sekolah dasar.Data hasil penelitian menunjukkan bahwa distribusi tingkat pendidikan responden terbanyak adalah SMA/SMK yaitu 
sebanyak 18 orang (60\%). Distribusi tingkat pendidikan SMP 8 orang (26\%), SD 3 orang $(10 \%)$ dan Perguruan Tinggi satu orang (3,3\%).Latar belakang pendidikan formal merupakan salah satu faktor penunjang untuk memahami pola pengembangan dan manajemen usaha peternakan babi (Suranjaya et al., 2017).

Salah satu indikator pada tingkat sosial rumahtangga petani peternak adalah pekerjaan.Sebagian petani peternak babi bekerja sebagai petani dan sebagian berusaha di luar bidang usahatani.Pekerjaan responden sesuai dengan hasil penelitian adalah ; petani, peternak, PNS, supir, dagang, dan wiraswasta. Pekerjaan terbanyak dari 30 responden adalah wiraswasta 13 responden (43,3\%), petani 8 responden (26,6\%),peternak 4 responden (13,3\%), dagang 3 responden (10\%), supir 1 responden (3,3\%), dan PNS 1 responden $(3,3 \%)$.

Pengalaman juga sebagai salah satu faktor yang menentukan keberhasilan suatu usahatani.Faktor pengalaman sangat ditentukan oleh lamanya usaha dari responden dalam menjalankan usaha peternakan babi.Pengalaman beternak adalah lamanya seseorang berkecimpung dalam usaha ternak itu (Suranjaya et al, 2017).Berdasarkan hasil penelitian bahwa lamanya responden dalam mengelola usaha ternak babi berkisar antara 1- 40
tahun.Responden sebanyak 18 orang (60\%) memiliki pengalaman berusaha antara 1-10 tahun, 8 responden $(26,66 \%)$ sekitar 11-20 tahun, 2 responden $(6,67 \%)$ sekitar 21-30 tahun dan 2responden $(6,67 \%)$ di atas 31 tahun.Hasil penelitian Suranjaya et al. (2017) bahwa 92\% responden memiliki pengalaman beternak lebih dari 5 tahun.

Faktor produksi yang digunakan petani peternak babi dalam mengembangkan usahanya diantaranya kandang, tenaga kerja dan pakan.Perubahan faktor produksi tersebut berpengaruh terhadap produksi ternak babi.Peningkatan produksi ternak babi perlu mendapat perhatian penting dari berbagai pihak. Hal ini disebabkan karena usaha ternak babi di wilayah penelitian memiliki potensi pasar yang sangat menggembirakan.Ternak babi dalam hal ini memiliki sifat-sifat dan kemampuan yang menguntungkan (Gobai et al., 2013), dan sebagai salah satu usaha yang potensial untuk dikembangkan (Aku et al, 2013).Ternak babi dan atau produk olahannya cukup potensial sebagai komoditas ekspor nasional (Kementerian Pertanian, 2012), danpasarnya masih terbuka lebar ke berbagai Negara seperti Singapura dan Hongkong. Keunggulan ternak babi lainnya adalah volume impornya dapat dikatakan nol (Kementerian Pertanian, 2012) 
Kandang merupakan hal yang sangat penting dalam menujang keberhasilan usaha peternakan babi (Sinaga dan Martin, 2010).Kandang merupakan tempat menampung ternak babi yang dibuat di sekitar rumah (Mengu et al. 2017).Kandang dalam penelitian ini dibagi dua macam yakni kandang induk dan kandang starter.Hasil penelitian menunjukkan bahwa sebagian petani peternak di Kecamatan Sonder menyewakan kandangnya kepada petani peternak lainnya. Indikasinya sebagian petani peternak babi sebagai responden tidak membangun kandang tetapi menyewa kandang dari petani peternak yang lain. Kandang babi induk disewa dengan harga $\mathrm{Rp}$ 700.000/tahun dan kandang fase starter Rp1.000.000/tahun. Kandang babi induk berukuran 2,5x3 m, kandang starter ukurannya $4 \times 5$ m untuk 10 ekor dan 3x8 m untuk 20 ekor. Peralatan yang digunakanumumnya terdiri dari sekop, ember, sapu, selang air dan kabel listrik.

Penggunaan tenaga kerja merupakan alokasi tenaga kerja keluarga yang digunakan dalam proses produksi usaha ternak babi. Hasil penelitian menunjukkan bahwa pemeliharaan ternak babi secara rutin setiap hari dikerjakan peternak itu sendiri.Hal ini sesuai dengan penelitian Mengu et al. (2017).Alokasi tenaga kerja petani peternak meliputi mencampur pakan ternak, membersihkan kandang, memandikan ternak babi, dan memberi pakan.Waktu yang digunakan adalah2-3 jam/hari.Upah pekerja yang berlaku secara umum adalah sewa pejantan Rp.150.000 sampai bunting, untuk menjaga babi yang sedang beranak Rp.500.000 per dua minggu.Upah pemelihara ternak babi yang berlaku di wilayah penelitian adalah Rp.1.000.0002.000.000/bulan.

Pakan adalah salah satu faktor penting dalam usaha ternak babi (Hardyastuti, 2011).Periode penggemukan ternak babi membutuhkan komposisi pakan yang berkualitas baik yang mengandung energi, protein, mineral, vitamin dan air (Sinaga dan Martin, 2010).Hasil penelitian menunjukkanbahwa pakan yang digunakan terdiri atas rata-rata jagung $0,80 \mathrm{~kg}$, konsentrat $0,44 \mathrm{~kg}$, dedak $0,19 \mathrm{~kg}$, mineral $0,009 \mathrm{~kg}$ dan butiran 0,33 kg. Pemberian pakan kepada ternak babi sesuai hasil penelitian dilakukan 2 kali dalam sehari.Pemberian sesuai hasil penelitian Mengu et al. (2017). Menurut Santa dan Wantasen (2018) harga pakan berpengaruh nyata terhadap produksi. 
Tabel 1.Hasil Estimasi Persamaan Faktor-Faktor yang Mempengaruhi Produksi Ternak Babi

\begin{tabular}{cccc}
\hline Variabel & $\begin{array}{c}\text { Parameter } \\
\text { Estimasi }\end{array}$ & $\begin{array}{c}\text { Nilai } \\
\text { t-hit }\end{array}$ & Pr $>(t)$ \\
\hline Intercept & -179.152 & & \\
LKB & 9.743370 & 1.07 & 0.2936 \\
TKB & 76.20979 & 2.09 & $0.0467 * *$ \\
PKN & 1.078108 & 2.43 & $0.0222^{* *}$ \\
\hline
\end{tabular}

**Signifikan pada $\propto 0.05(\mathrm{P}<0.05$

Variabel-variabel

yang

mempengaruhi produksi ternak babi diantaranya variabel luas kandang babi (LKB), pakan (PKN) dan tenaga kerja bapak (TKB).Pengaruh faktor-faktor produksi terhadap produksi babi dianalisis dengan menggunakan analisis regresi linear berganda. Hasil analisis dengan menggunakan software program SAS 9,4 dinyatakan seperti pada Tabel 1

Data estimasi pada Tabel 1 kemudian dirumuskan dalam bentuk persamaan regresi.Persamaan regresi faktor-faktor yang mempengaruhi produksi ternak babi dinyatakan seperti pada persamaan (1).

$\mathrm{PBB}=-179.152+9.743370 \mathrm{LKB}+$ 1.078108PKN+76.20979TKB ...(1)

Keterangan : $\mathrm{PBB}=$ Produksi Ternak Babi LKN= Kandang $\left(\mathrm{M}^{2}\right)$

$\mathrm{PKN}=$ Pakan $(\mathrm{Kg})$

$\mathrm{TKB}=$ Tenaga Kerja bapak $(\mathrm{HOK})$

Berdasarkan Persamaan

menunjukkan bahwa nilai intersep sebesar -179.152, artinya tanpa perubahan penggunaan input kandang babi (LKB), pakan (PKN) dan tenaga kerja bapak
(TKB) maka produksi babi berkurang sebesar 179,152 Kg. Kondisi ini menunjukkan bahwa pengembangan ternak babi dilakukan dengan menggunakan faktor produksi berupa kandang, tenaga kerja dan pakan.

Nilai koefisien regresi variabel luas kandang (LKB) sebesar 9.743370 Kg, artinya bila luas kandang bertambah $1 \mathrm{~m} 2$ maka produksi babi naik sebesar $9.74 \mathrm{Kg}$, ceteris paribus. Nilai Koefisien dari variabel tenaga kerja bapak (TKB) sebesar 76.20979, artinya bila tenaga kerja bapak (TKB) bertambah 1 HOK maka produksi babi naik sebessar $76.21 \mathrm{Kg}$, ceteris paribus.Nilai Koefisien dari variabel pakan (PKN) sebesar 1.078108, artinya bila pakan $(\mathrm{PKN})$ bertambah $1 \mathrm{Kg}$ maka produksi babi naik sebessar $1.07 \mathrm{Kg}$, ceteris paribus.

Hasil analisis uji $\mathrm{F}$ menunjukkan bahwa faktor-faktor produksi luas kandang (LKB), pakan (PKN) dan tenaga kerja bapak (TKB) secara besama-sama berpengaruh nyata terhadap produksi sapi pada tingkat kepercayaan 95\% $(\mathrm{P}<0,05)$ 
Nilai koefisien determinasi $\left(\mathrm{R}^{2}\right)$ sebesar 0.48748, artinya naik turunya produksi babi sebesar $48.75 \%$ dipengaruhi oleh naik turunnya variabel luas kandang (LKB), pakan $(\mathrm{PKN})$, dan tenaga kerja bapak (TKB), sisanya $51.15 \%$ dipengaruhi oleh variabel lain yang tidak dimasukkan dalam model analisis. Variabel lain tersebut diantaranya manajemen usaha ternak babi dan faktor sosial ekonomi petani peternak.

Hasil analisis uji $t$ pada menunjukkan bahwa pengujian secara parsial terhadap variabel luas kandang (LKB) bepengaruh tidak nyata (non signifikan) terhdap produksi babi $(\mathrm{P}>0.10)$.Kondisi ini menunjukkan perubahan luas kandang pengaruhnya kecil terhadap perubahan produksi ternak babi.

Pengujian secara parsial terhadap variabel tenaga kerja bapak (TKB) berpengaruh nyata (signifikan) terhadap produksi babi $\quad(\mathrm{P}<0.05)$.Signifikansi variabel tenaga kerja bapak (TKB) terhadap produksi babi menunjukkan bahwa alokasi tenaga kerja keluarga petani peternak babi menentukan perubahan produksi ternak babi.Menurut hasil penelitian Coulibaly (2009), rata-rata jam kerja tenaga kerja di peternakan babi adalah 0,29 jam per ekor ternak babi.

Pengujian secara parsial terhadap variabel pakan $(\mathrm{PKN})$ berpengaruh nyata terhadap produksi babi $(\mathrm{P}<0.05)$.
Signifikansi variabel pakan (PKN) terhadap produksi babi menunjukkan bahwa pakan menentukan perubahan produksi ternak babi. Sesuai hasil penelitian Hardyastuti (2011) bahwa biaya pakan dalam usaha ternak babi berkisar antara 70-80 \% dari total biaya produksi. Petani peternak perlu menggunakan bahan pakan yang murah. Hal ini karena menurut Ariana et al (2014) bahwa pemanfaatan bahan pakan murah pada level yang tepat akan memberikan keuntungan ekonomi.

\section{KESIMPULAN}

Faktor-faktor produksi pakan, tenaga kerja dan luas kandangsecara bersama-sama berpengaruh nyata terhadap produksi babi.

\section{DAFTAR PUSTAKA}

Aku, A.S., T. Saili dan Amiruddin. 2013. Sebaran, struktur populasi dan kinerja reproduksi babi lokal di Kecamatan Tinangge Kabupaten Konawe Selatan. Agriplus, Jurnal. 23 (03) :188-192.

Ariana, I.N.T., A.W. Puger., A.A. Oka dan N.I.P. Sriyani. 2014. Analisis ekonomi usaha ternak babi dengan pemberian sekam padi dalam ransum yang mengandung limbah hotel. Jurnal Ilmiah Peternakan 17 (2) : 71-74.

Aritonang, R.dan R. Lerbin.2005, Kepuasan Pelanggan, Pengukuran dan Penganalisaan Dengan SPSS, Jakarta. PT Gramedia Pustaka Utama.

Coulibaly, A. L. 2009. Hog production costs-what is needed to stay 
competitive?. Advances in Pork Production (20) : 97-106.

Direktorat Jendral Peternakan. 2013. Statistik Peternakan dan Kesehatanhewan. Livestock And Animal Health Statistic 2013. Jakarta. Direktorat Jendral Peternakan dan Kesehatan Hewan. Kementrian Pertanian Indonesia

Gobai, F., Hartoko dan Rachmawati. 2013. Hubungan antara periode beranak dengan litter size dan bobot lahir anak babi di perusahaan peternak babi, Kemangkon Purbalingga. Jurnal Ilmiah Peternakan 1 (3): 1114-1119.

Hardyastuti, S. 2011. Kajian Biaya Produksi pada usaha peternakan babi. Jurnal Sosek Peternakan Unibraw Malang.12(1) : 136-143

Kementerian Pertanian. 2012. Pedoman Pelaksanaan Penataan Usaha Budidaya Babi Ramah Lingkungan. Departemen Pertanian, Jakarta.

Kojo R.E, V.V.J Panelewen, M.A.V Manese, N Santa . 2014. Efisiens penggunaan input pakan dan keuntungan pada usaha ternak babi di Kecamatan Tateran Kabupaten Minahasa Selatan. Fakultas Peternakan Universitas Sam Ratulangi Manado.Jurnal Zootek. 34(1): 62-74

Mangun, N. 2007. Analisi Potensi Ekonomi Kabupaten dan Kota di Sulawesi Tengah. Pascasarjana Universitas Diponegoro, Semarang.

Mengu, Y.S., V.R. Lole dan S.S. Niron. 2017. Kinerja produksi dan ekonomi usaha penggemukan ternak babi program pengembangan usaha agribisnis pedesaan (PUAP) di Kecamatan Adonara Timur. Jurnal Nukleus Peternakan 4 (1) : 71-82.

Nuryasa. 2015. Ayo beternak babi. Jurnal Bakti Saraswati. 4 : 118-126
Sinaga S, dan S. Martini. 2010. Pemberian berbagai dosis curcuminoid pada ransum babi periode starter dan efisiensi ransum. Jurnal Ilmu Ternak. 1(10): 95-101.

Suranjaya, I.G., M. Dewantari., I.K.W. Parimartha dan I.W. Sukanata. 2017. Profile usaha peternakan babi skala kecil di Desa Puhu Kecamatan Payangan Kabupaten Gianyar. Majalah Ilmiah Peternakan 20 (2) : 79-83.

Tilman, A. D. H., Hartadi, S. Reksohadipiojo, R. Prawirokusomo, S, Lepdosoekodjo. 1986. Ilmu Makanan Ternak Dasar. Fakultas Peternakan UGM Yogyakarta. 